\title{
Contamination, Identification and Distribution of Microplastic in Sediments, Surface Seawater and Four Species of Fish on the Northern Shores of the Persian Gulf, south of Iran
}

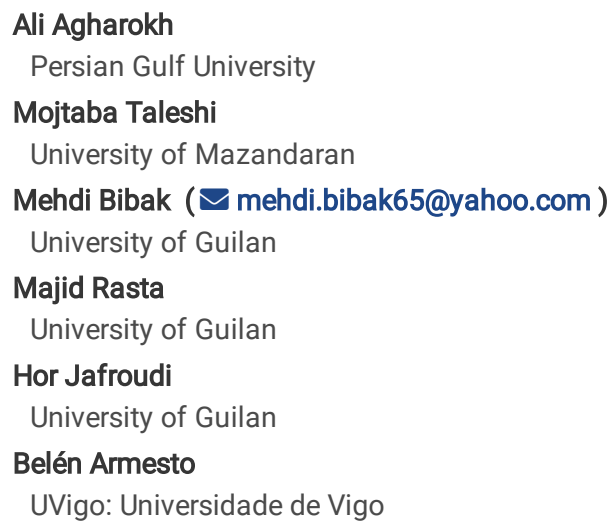




\section{Abstract}

The purpose of this study is to investigate Microplastic pollution (MPs) in important ports of the northern coast of the Persian Gulf. MPs were identified on the northern shores of the Persian Gulf in three compartments: sediment, seawater, and four species of fish. In December 2019, sampling was conducted in 7 sampling areas. In this study, 357 MPs were identified in all samples. The predominant polymer in MPs was polypropylene (PP) and later polyethylene (PE). The most polluted areas in terms of MPs in sediments, seawater, and fish were Bushehr, Bandar Abbas, and Qeshm. The fiber was the predominant form of MPs in all sampling stations and those samples taken from the surface seawater, sediments, and fish. The presence of fishing ports with fishing tools, commercial ports, the tourist attractions, and the tourist industry in these areas was an important factor controlling the distribution of MPs in these areas.

\section{Introduction}

Microplastic contamination exists in all oceans of the world. It is considered as a permanent phenomenon, as it blatantly endangers different marine animal species at different nutritional levels-(Christaki et al., 1998) zooplankton (Cole et al., 2011), birds (Van Franeker et al., 2011), sea turtles (Tourinho et al., 2010) and marine mammals-are affected by and exposed to Microplastic pollution (MPs) contamination.

MPs can enter the environment directly or following the decomposition of larger plastics. MPs are difficult to remove if present in the environment, especially in marine environments. It is currently impossible to remove MPs from the sea. Significant amounts of these MPs are present in coastal sediments, water columns and even seawater. MPs can be transferred through the food chain as a process, through which marine prey items ingested MPs are consumed. MPs' introduction to fish diet occurs across taxa (Gouin, 2020; Roch et al., 2020) particularly predatory fish (S. forsteri, O. ruber, and C. are/ in the present study). Peda et al. (2016) studied the physiological effects of MPs contaminant and indicated that fish exposure to MPs makes some changes in their routine functions. Other researchers examined these impacts and demonstrated that MPs contamination results in changed swimming function, abnormal swimming behavior, and lethargy in these fish. These factors suggest the critical priority of the present work for assessing MPs contamination and MPs in fish.

MPs particles have also been reported in the gastrointestinal tract of many species of marine fish (Ferreira et al., 2016., Rochman et al., 2015; Neves et al. 2015), which are among the largest and most diverse groups of animals of high biological and economic importance. The risks associated with plastic particles include physical effects of materials (von Moos et al., 2012; Rochman et al., 2013), chemical compounds of plastics and chemicals adsorbed from the environment (Hirai et al., 2011), (e.g., stable bioaccumulation and toxic substances PBTs) (Holmes et al., 2012) and metals (Salvati et al., 2011).

Regarding the contamination of MPs in aquatic environments, when the particles are consumed by various organisms, they can penetrate the food web and may result in bioaccumulation (Kashiwada, 2006; Akdogan and Guven, 2019; Bibak et al., 2020). Studies on the effects of bioaccumulation indicate that the uptake of polystyrene (PS) particles by human lung cancer cells is essentially irreversible. Also, the concentration of intracellular particles shows a linear increase by time (Wright et al., 2013). In addition, small latex particles (<50 nm) can accumulate in testicular tissue, liver, blood, and brain of fish (Lönnstedt and Eklöv, 2016). This means that MPs particles are able to cross the blood-brain barrier. The wall plays a critical role in protecting the brain against toxins and is also essential for maintaining homeostasis and neural function in the brain. The physical effects of MPs on marine creatures are intestinal obstruction, inhibition of gastric secretion, reduction of nutritional stimuli, reduction of steroid hormone levels, delayed ovulation, and lack of successful reproduction (Auta et al., 2017; Hermabessiere et al., 2017). MPs particles chemically and physically impair the function and development of fish larvae. Polystyrene particles prevent hatching as their consumption reduces the growth rate and changes the food preference and instinctive behaviors of fish larvae. Besides, when fish larvae are exposed to these particles, they cease to respond to olfactory alarm signals, causing the mortality rate as a result of predator stimulation to increase significantly (Zhu et al., 2019; Arias et al., 2019). Moreover, consumption of polystyrene also changes the behavior of fish and disrupts the fat metabolism of freshwater fish (Pedà et al., 2016). MPs enter aquatic environments through various routes such as human wastewater, effluents discharged by factories and industries, shipping, and oil activities.

The physical and chemical hazards posed by the contamination of MPs consumed by aquatic organisms at various food levels, as the evidence of the uptake and transmission of chemical contaminants from plastics by and to aquatic creatures demonstrated the necessity of conducting this research (Arthur et al., 2009; Bakir et al., 2014). The scarce information (Kor and Mhedinia, 2020) about the presence and distribution of the MPs particles in the Persian Gulf makes this study necessary and relevant. The most relevant aspect of the present work is the assessment of MPs contamination in different areas of the northern coast of the Persian Gulf (coast of Iran) and the study of these MPs in different compartments (sediment, seawater and fish). This can allow improve our knowledge about the MPs travelling, sources, types and presence of this contamination in commercial fish in this region. However, other studies have been conducted in southern Iran, such as Hosseini et al., 2020; Kor, K., Mehdinia, A., 2020; Aliabad et al., 2019, But this study investigated microplastic contamination in water, sediment and fish as well as their relationship with each other in sampling areas for the first time.

\section{Materials And Methods}

\subsection{Sampling region}

The northern shores of the Persian Gulf were divided into seven sampling stations in December 2019. The stations are located in three provinces of Khuzestan, Bushehr, and Hormozgan (Fig. 1). In Khuzestan province, was selected the sampling station of Hendijan in areas with fishing ports and residential houses. In Bushehr province, we selected Emam Hassan, Genaveh, and Bushehr stations. These three sampling regions are significant commercial, and fishing fields near the residential buildings, and the Bushehr sampling region is considered one of the critical tourist areas. In

Page $2 / 13$ 
Hormozgan province, we chose Bandar Lengeh, Bandar Abbas, and Qeshm for sampling. Lengeh port is one of the important fishing and commercial areas in this province. Bandar Abbas and Qeshm are not only considered as important fishing and commercial ports, but also essential tourist areas in the southern region of Iran.

\subsection{Sample collection}

Triplicate surface waters samples were collected from each site (A to G) by a neuston net with an opening diameter of $50 \mathrm{~cm}$, a length of $180 \mathrm{~cm}$, and a mesh size of $50 \mu \mathrm{m}$ (Thompson et al., 2004). The net was towed for $10 \mathrm{~min}$ at a speed of $3 \mathrm{knots}$ on the water surface (depth of $\approx 30 \mathrm{~cm}$ ) and in the direction of the wind (Free et al. 2014). The collected samples were washed in glass containers at the end of the net, which has a tiny container. Next, they were stabilized with 70\% isopropyl alcohol to prevent water from putrefaction (Martins and Sobral, 2011; Toumi et al., 2019) and transferred to the laboratory a $4^{\circ} \mathrm{C}$.

The samples were initially filtered through a metal sieve with a mesh size of $5 \mathrm{~mm}$ so they can separate large plastic pieces. Afterward, the water sample was oxidized by wet peroxide and digested in the presence of divalent iron as a catalyst for unstable organic matter. Hydrogen peroxide was added until no other organic matter could be seen. In the next step, the MPs were separated from other particles using NaCl $1.2 \mathrm{~g} \mathrm{~cm}^{-3}$ (Graca et al., 2017 ) solution. Finally, the supernatant was filtered through a $5 \mu \mathrm{m}$ mesh sieve to preserve MPs. Then, they were washed with ionized water for removing the salt and then were dried at $60^{\circ} \mathrm{C}$.

In the sediment sample, the sediment surface was sampled (from a depth of $5 \mathrm{~cm}$ ) at the same time as water sampling. This sampling was performed using a stainless-steel core (Claessens et al., 2011; Löder and Gerdts, 2015). Approximately $1 \mathrm{~kg}$ sediment of each site was collected and placed in glass containers and packaged with aluminum foil to avoid air contamination. Following the transfer of sediments to the lab, the sediment was kept at $80^{\circ} \mathrm{C}$ to dry completely (Corcoran, 2015). The temperature is less than the melting point and deformation of polymers, so it is not expected that the shape of the polymers will change. One hundred grams dry weight of sediments was used for lab analysis. All sampling vessels were washed three times with ionized water before sampling. The sediment was thoroughly mixed with sodium hexametaphosphate $0.5 \mathrm{M}$ and transferred to a 5 -liter container: low-density materials such as MPs remain on the surface of the water due to buoyancy. Next, the floating materials were completely passed through a $5 \mu \mathrm{m}$ Whatman cellulose nitrate filter. This action was repeated three times, and $500 \mathrm{~g}$ of the sieved sediment sample became a $100-\mathrm{g}$ residue at last. Afterward, a zinc chloride solution $\left(\mathrm{ZnCl}_{2}\right)$ was added to it for $48 \mathrm{~h}$ to separate MPs. Then the floating materials were filtered using a $5 \mu \mathrm{m}$ filter paper. The ionized water was poured onto the filter so that $\mathrm{ZnCl}_{2}$ was rinsed. In the end, the filter was kept at $60^{\circ} \mathrm{C}$ to dry completely.

A total of 280 fish specimens were bought from local fishermen in the Persian Gulf from 4 commercial species (Otolithes ruber, Liza abu, Sphyraena forsteri and Cynoglossus are) (40 fish per region). The fishes were transferred to the laboratory via a cool box (Su et al., 2019) in which each individual was performed, and its total length-TL $(\mathrm{cm})$, weight-TW $(\mathrm{g})$ were measured. The weight of gastrointestinal tract (W of GIT) was also measured (Table 1).

Table 1

The biometric of all of the species fish (mean \pm SD), TL (Total length), TW (Total weight) and W of GIT (The weight of gastrointestinal tract)

\begin{tabular}{|llll|}
\hline $\begin{array}{l}\text { Biometrics } \\
\text { Species }\end{array}$ & $\begin{array}{l}\text { TL }(\mathrm{cm}) \\
\text { mean } \pm \text { SD }\end{array}$ & $\begin{array}{l}\text { TW }(g) \\
\text { mean } \pm \text { SD }\end{array}$ & $\begin{array}{l}\text { W of GIT(g) } \\
\text { mean } \pm \text { SD }\end{array}$ \\
\hline O. ruber & $29.50 \pm 1.31$ & $255.88 \pm 24.50$ & $24.7 \pm 0.7$ \\
\hline L. abu & $21.62 \pm 1.30$ & $123.62 \pm 19.54$ & $14.5 \pm 4.17$ \\
\hline S. forsteri & $52.86 \pm 5.84$ & $589.57 \pm 151.71$ & $38.71 \pm 13.95$ \\
\hline C. arel & $29.44 \pm 2.82$ & $139.25 \pm 64.54$ & $3.28 \pm 2$ \\
\hline
\end{tabular}

The GI tract of each individual was transferred to a $250 \mathrm{~mL}$ container and loaded with $\mathrm{KOH} 10 \%$ (potassium hydroxide solution). Recent studies have recognized $\mathrm{KOH} 10 \%$ as the most suitable solution for the digestion of intestinal contents of fish. The added solution was at least three times the volume of biological material. And the samples were incubated within five days to ensure the entire digestion via the digestive tract at $60^{\circ} \mathrm{C}($ Savoca et al., 2019$)$. Afterward, the residual substance was filtered through $5 \mu \mathrm{m}$ Whatman paper. The filters were dried in a Petri dish at $60^{\circ} \mathrm{C}$.

At the end, the MPs were removed from other components and then detected by using a microscope ZTX-E with 40X magnification. The chemical composition and morphological properties of each MPs were identified by scanning electron microscope (SEM; Hitachi SU 3500 ) and an energydispersive X-ray microanalyzer (EDS; Amptek, USA). Besides, microplastics were analyzed using ATR-FTIR by a Nicolette Nexus 470 (Thermo Nicolet, USA) connected to OMNIC Software. The spectral range of each spectrum was in $650-4000 \mathrm{~cm}^{-1}$ region and $4 \mathrm{~cm}^{-1}$ resolution. Before each test, a background air spectrum was recorded (Qiu et al., 2016).

\subsection{Quality control and quality assurance}

To prevent air-borne contamination, nitrile gloves and cotton lab coats were worn in the whole steps of experiments. All apparatuses and work surfaces were rinsed with alcohol $70 \%$ before and after using. All solutions were filtered before using to decrease the possibility of contamination. Aluminum foils were used to cover samples during the experiments. Three control blanks containing pure water were run during analyze. Final data were corrected through subtracting the blank contamination from particles counted in samples. 
The Kolmogorov-Smirnov test examined the normality of the data. ANOVA test was used to compare samples (the significance level was 0.05). Excel 2019 and MiniTab 17 were used to draw graphs, and SPSS 22 was used for the statistical analysis of the data.

\section{Results}

\subsection{Number of MPs per sampling site and compartments}

The total amount of collected MPs were 130,133, and 94 in surface waters, sediments, and studied fish species, respectively. After a comparison of the number of MPs in samples taken from the different compartments, the highest numbers of MPs were collected in Bandar Abbas, Bushehr and Lengeh regions were those of the surface seawater. Also, they were highest in Emam Hassan, Genaveh, and Qeshm regions in collected sediment samples; only in the Hendijan region, they were highest in samples taken from L. abu species (Fig. 2).

The highest MPs contamination was determined in fish samples taken from 0 . ruber species, and in the second rank, the highest levels of MPs were collected in L. abu, C. arel, and S. forsteri, respectively.

Also, the contaminant of MPs was assessed for each fish species in the sampling regions, and it was determined that the most contaminated regions based on the existed MPs in O. ruber species were found to be Qeshm. Other regions showed the following pattern of MP contaminants in these fish species:

Qeshm > Bushehr > Lengeh > Bandar Abbas- Hendijan- Emam Hassan > Genaveh

The results suggested that the most MPs-contaminated region for L. abu fish was the sampling region of Hendijan and Bushehr, Lengeh, Bandar Abbas, Qeshm, and Emam Hassan regions were showed to be the most contaminant ones, respectively.

The Percentage of MPs in S. forsteri species showed that the most contaminated region for the number of MPs in this fish species was Bushehr and Hendijan regions; Lengeh, Qeshm, Emam Hassan, and Bandar Abbas regions had the highest contamination, respectively. The MPs identified in $C$. arel proved that the most contaminant regions based on the numbers of MPs in this species were Lengeh and Bandar Abbas regions, and in the next level of contamination, there were Qeshm, Bushehr, Emam Hassan, Hendijan, and Genaveh regions, respectively (Fig. 2). After comparing the numbers of MPs in all studied fish species, it was determined that Bushehr was the most contaminant region based on the numbers of MPs in all studied species, followed by Qeshm, Hendijan, Lengeh, Bandar Abbas, Emam Hassan, and Genaveh regions. The most contaminant region based on the numbers of MPs in all regions was Qeshm and Bandar Abbas for sediment and seawater respectively (Fig. 2).

According to the collected MPs in all sampling (sea water, sediment and fish) cases, Bushehr, Bandar Abbas and Qeshm were the most contaminated areas in terms of number of MPs, respectively.

\subsection{Average size of MPs}

The largest average size of MPs in seawater was Genaveh region with $4.07 \mathrm{~mm}$ and the smallest average size in Bandar Abbas was $1.08 \mathrm{~mm}$. The largest size of MPs identified in the seawater sample was identified in Genaveh region with a size of $16 \mathrm{~mm}$, characterized as mesoplastic. Also, in sediments, the maximum average size of MPs was $2.36 \mathrm{~mm}$ in Genaveh region and the lowest was 0.7 in Bandar Abbas. The largest size of MPs in sediments was also identified in Genaveh region with a value of $5 \mathrm{~mm}$, which is in the size limit for microplastics. In fishes, it was determined that the highest average size of MPs among all studied species was related to seawater fish with an average of $5.13 \mathrm{~mm}$ in Hendijan region. The largest size of MPs with a size of $8.2 \mathrm{~mm}$ related to the same fish which was identified in Hendijan region. Table 2 shows the average, minimum, and maximum size of MPs (Table 2). 
Table 2

Mean size of MPs (mean \pm S.D), and range $(\mathrm{mm})$ in the different species

\begin{tabular}{|c|c|c|c|c|c|c|c|c|c|c|c|c|c|c|}
\hline \multicolumn{15}{|l|}{ Regions } \\
\hline \multirow[b]{2}{*}{ Species } & \multicolumn{2}{|c|}{ Hendijan } & \multicolumn{2}{|c|}{ Genaveh } & \multicolumn{2}{|c|}{ Emam Hassan } & \multicolumn{2}{|c|}{ Bushehr } & \multicolumn{2}{|c|}{ Bandar Abbas } & \multicolumn{2}{|l|}{ Lengeh } & \multicolumn{2}{|l|}{ Qeshm } \\
\hline & $\begin{array}{l}\text { Mean } \\
\pm \text { SD }\end{array}$ & Range & $\begin{array}{l}\text { Mean } \\
\pm S D\end{array}$ & Range & $\begin{array}{l}\text { Mean } \\
\pm \text { SD }\end{array}$ & Range & $\begin{array}{l}\text { Mean } \\
\pm \text { SD }\end{array}$ & Range & $\begin{array}{l}\text { Mean } \\
\pm \text { SD }\end{array}$ & Range & $\begin{array}{l}\text { Mean } \\
\pm S D\end{array}$ & Range & $\begin{array}{l}\text { Mean } \\
\pm \text { SD }\end{array}$ & Range \\
\hline O. ruber & $\begin{array}{l}5.13^{a b} \\
\pm 2.65\end{array}$ & $\begin{array}{l}3.5- \\
8.2\end{array}$ & $\begin{array}{l}1.85^{\mathrm{ab}} \\
\pm 1.55\end{array}$ & $\begin{array}{l}2.5- \\
4.7\end{array}$ & $\begin{array}{l}1.43^{\mathrm{ab}} \\
\pm 0.94\end{array}$ & $\begin{array}{l}0.7- \\
2.5\end{array}$ & $\begin{array}{l}2.86^{a b} \\
\pm 1.98\end{array}$ & $0.5-7$ & $\begin{array}{l}1.85^{\mathrm{ab}} \\
\pm 1.07\end{array}$ & $\begin{array}{l}0.3- \\
4.1\end{array}$ & $\begin{array}{l}1.27^{\mathrm{ab}} \\
\pm 0.82\end{array}$ & $\begin{array}{l}0.3- \\
2.1\end{array}$ & $\begin{array}{l}1.34^{\mathrm{ab}} \\
\pm 0.69\end{array}$ & $\begin{array}{l}0.6- \\
2.3\end{array}$ \\
\hline L. $a b u$ & $\begin{array}{l}3.24^{\mathrm{ab}} \\
\pm 1.16\end{array}$ & $\begin{array}{l}1.5- \\
4.6\end{array}$ & - & - & $\begin{array}{l}1.91^{\mathrm{ab}} \\
\pm 1.25\end{array}$ & $\begin{array}{l}1.02- \\
2.8\end{array}$ & $\begin{array}{l}3.15^{\mathrm{ab}} \\
\pm 1.28\end{array}$ & $\begin{array}{l}1.5- \\
5.5\end{array}$ & $\begin{array}{l}1.86^{\mathrm{ab}} \\
\pm 1.38\end{array}$ & $\begin{array}{l}0.7- \\
3.4\end{array}$ & $\begin{array}{l}1.6^{\mathrm{ab}} \\
\pm 1.48\end{array}$ & $\begin{array}{l}0.6- \\
3.8\end{array}$ & $\begin{array}{l}2.5^{\mathrm{ab}} \\
\pm 0.95\end{array}$ & $\begin{array}{l}1.5- \\
3.4\end{array}$ \\
\hline S.forsteri & $\begin{array}{l}2.77^{a} \\
\pm 2.11\end{array}$ & $\begin{array}{l}1.1- \\
6.2\end{array}$ & - & - & $\begin{array}{l}1.16^{\mathrm{a}} \\
\pm 0.19\end{array}$ & $\begin{array}{l}1.02- \\
1.3\end{array}$ & $\begin{array}{l}2.72^{\mathrm{a}} \\
\pm 1.49\end{array}$ & $1-5$ & $\begin{array}{l}3.1^{\mathrm{a}} \pm \\
1.41^{-}\end{array}$ & $\begin{array}{l}2.1- \\
4.1\end{array}$ & $\begin{array}{l}2.36^{\mathrm{a}} \\
\pm 1.67\end{array}$ & $\begin{array}{l}0.6- \\
4.1\end{array}$ & $\begin{array}{l}3.15^{\mathrm{a}} \\
\pm 1.06\end{array}$ & $\begin{array}{l}2.4- \\
3.9\end{array}$ \\
\hline C.arel & $\begin{array}{l}1.2^{\mathrm{a}} \pm \\
0.84\end{array}$ & $\begin{array}{l}1.1- \\
1.3\end{array}$ & $\begin{array}{l}2.3^{\mathrm{a}} \pm \\
1.41\end{array}$ & $\begin{array}{l}1.3- \\
3.3\end{array}$ & $\begin{array}{l}1.26^{\mathrm{a}} \\
\pm 0.11\end{array}$ & $\begin{array}{l}0.7- \\
1.7\end{array}$ & $\begin{array}{l}1.26^{\mathrm{a}} \\
\pm 0.75\end{array}$ & $\begin{array}{l}0.7- \\
2.2\end{array}$ & $\begin{array}{l}2.71^{\mathrm{a}} \\
\pm 2.13\end{array}$ & $\begin{array}{l}0.9- \\
5.8\end{array}$ & $\begin{array}{l}1.88^{\mathrm{a}} \\
\pm 1.35\end{array}$ & $\begin{array}{l}0.3- \\
4.3\end{array}$ & $\begin{array}{l}1.67^{\mathrm{a}} \\
\pm 0.84\end{array}$ & $\begin{array}{l}0.7- \\
2.6\end{array}$ \\
\hline Seawater & $\begin{array}{l}2.54^{\mathrm{a}} \\
\pm 1.77\end{array}$ & $0.4-5$ & $\begin{array}{l}4.07^{\mathrm{a}} \\
\pm 3.43\end{array}$ & $\begin{array}{l}0.3- \\
16\end{array}$ & $\begin{array}{l}1.61^{\mathrm{a}} \\
\pm 1.02\end{array}$ & $\begin{array}{l}0.3- \\
4.7\end{array}$ & $\begin{array}{l}2.33^{\mathrm{a}} \\
\pm 1.25\end{array}$ & $0.5-5$ & $\begin{array}{l}1.08^{a} \\
\pm 0.89\end{array}$ & $\begin{array}{l}0.3- \\
4.7\end{array}$ & $\begin{array}{l}1.33^{\mathrm{a}} \\
\pm 1.25\end{array}$ & $0.3-5$ & $\begin{array}{l}1.56^{\mathrm{a}} \\
\pm 1.50\end{array}$ & $\begin{array}{l}0.3- \\
6.2\end{array}$ \\
\hline Sediment & $\begin{array}{l}2.36^{\mathrm{a}} \\
\pm 1.41\end{array}$ & $\begin{array}{l}0.7- \\
4.5\end{array}$ & $\begin{array}{l}2.06^{\mathrm{a}} \\
\pm 1.54\end{array}$ & $0.5-5$ & $\begin{array}{l}0.7^{\mathrm{a}} \pm \\
0.09^{-}\end{array}$ & $\begin{array}{l}0.5- \\
1.2\end{array}$ & $\begin{array}{l}1.39^{a} \\
\pm 0.61\end{array}$ & $0.5-3$ & $\begin{array}{l}1.62^{\mathrm{a}} \\
\pm 1.16\end{array}$ & $\begin{array}{l}0.3- \\
4.5\end{array}$ & $\begin{array}{l}1.26^{\mathrm{a}} \\
\pm 0.44\end{array}$ & $\begin{array}{l}0.5- \\
2.5\end{array}$ & $\begin{array}{l}1.04^{\mathrm{a}} \\
\pm 0.62\end{array}$ & $\begin{array}{l}0.3- \\
2.4\end{array}$ \\
\hline \multicolumn{15}{|c|}{ Identical letters indicate no significant difference. $(P>0.05)$} \\
\hline Non-identi & letters & icate a & & $c_{-1}$ & $P<0.0$ & & & & & & & & & \\
\hline
\end{tabular}

\subsection{Size classification of MPs (mm)}

The 357 collected MPs were categorized according to sizes using SPSS 22 in three kinds of samples taken from surface water, sediment, and fish species. Accordingly, the collected MPs in fish are categorized into six groups based on their sizes. The dominant size (47\%) percentage belongs to the second size category $(0.67-1.69 \mathrm{~mm})$ in the collected MPs for all the studied fish species and the least numbers of MPs were found in the first size category of $(\leq 0.66 \mathrm{~mm})$.

Also, the size of MPs was categorized in samples taken from water and sediments. Accordingly, the collected MPs in surface waters were also categorized into six groups. The dominant numbers of MPs were found in the second group (46\%) $(0.48-1.62 \mathrm{~mm})$. The most frequently collected MPs in the sediments were found in the second size category $(40 \%)$, similar to fish and sea water, $(0.46-1.36 \mathrm{~mm})$. The other categories and the frequencies of MPs are reported, according to each size category in Fig. 3.

\subsection{Morphology of MPs}

Fibers, films, and fragments were identified in the accumulated MPs. The fiber was the predominant form of MPs in all sampling stations and those samples taken from the surface seawater, sediments, and fish. Also, fragments MPs types were more common than film-shaped ones in all the stations.

In Bushehr Port station, fiber-shaped MPs constituted only $66.66 \%$ of the total MPs forms, which are lower than in the other stations, or it can be said that the highest amount of film and fragment was also identified in this station. All taken MPs were fiber shaped at Emam Hassan station. In this station, there were no other forms of MPs in surface waters. Also, the shape proportion of MPs in other stations was reported according to the following pattern (Fig. 4).

Fibre Emam Hassan > Bandar Abbas $>$ Lengeh $>$ Qeshm $>$ Genaveh-Hendijan $>$ Bushehr

Fragment Genaveh > Bushehr $>$ Hendijan $>$ Qeshm > Lengeh $>$ Bandar Abbas $>$ Emam Hassan

Film Bushehr $>$ Hendijan $>$ Genaveh $>$ Emam Hassan- Bandar Abbas $>$ Lengeh $>$ Qeshm

Also, MPs morphology was assessed in the sediments. Hence, the highest-fiber-shaped MPs were gathered at Emam Hassan and Lengeh stations (as $100 \%$ ) and the lowest ones were at Hendijan station (60\%). The maximum numbers of the fragment and film-shaped MPs were also identified at Hendijan station. The different shapes of MPs at different stations for sediment sampling were according to the following pattern (Fig. 4).

Fibre Emam Hassan- Lengeh > Bushehr- Bandar Abbas > Genaveh > Qeshm > Hendijan

Fragment Hendijan > Genaveh > Qeshm > Bushehr > Bandar Abbas > Emam Hassan- Lengeh

Film Hendijan > Qeshm > Genaveh > Bushehr- Bandar Abbas- Emam Hassan- Lengeh

Regarding the fishes, although the fiber-shaped MPs were predominantly identified in fish, some of them can be sampled in other sampling stations. According to this study, the different shapes of MPs determined in Cynoglossus are in three regions of Hendijan, Genaveh and Emam Hassan were all 
fiber (100\%) and in other regions conformed from the following pattern: Bushehr Port (fiber: $80 \%$, fragment: 13\%, film: 7\%), Bandar Abbas Port (fiber: 60\%, fragment: 30\%, film: 10\%), Lengeh Port (fiber: 60\%, fragment: 25\%, film: 15\%), Qeshm Port (fiber: 75\%, fragment: 20\%, film: 5\%).

In S. forsteri, the collected MPs were all fiber-shaped (100\%) in all regions except in Hendijan and Bushehr, where the shape composition was as (fiber: $85.5 \%$, fragment: $11 \%$, and film: $3.5 \%$ ), and (fiber: $71 \%$, fragment: $27 \%$, and fiber: $2 \%$ ), respectively. In other areas, the collected MPs were identified as all fiber-shaped (100\%).

In L. abu fish, the MPs were identified with a shape composition of (fiber: $50 \%$, fragment: $35 \%$, and film: $15 \%$ ) only in Lengeh region, and in other regions, the collected MPs were all fiber-shaped.

In O. ruber fish, the MPs were identified with a shape composition of (fiber: $55 \%$, fragment: $30 \%$, and film: $15 \%$ ), (fiber: $90 \%$, fragment: $10 \%$ ), (fiber: $66.6 \%$, fragment: $23.3 \%$, and film: $10 \%$ ), (fiber: $60 \%$, fragment: $28 \%$, and film: $12 \%$ ) in Bushehr, Bandar Abbass, Lengeh and Qeshm regions, respectively, and in other regions, MPs were all fiber-shaped (Fig. 4).

\subsection{Color-based categories of MPs}

Color identification was performed by observation. The color-based categories of MPs indicated that among 130 collected MPs in samples taken from surface waters, $36,24,11$, and 59 ones were red, blue, white, and black, respectively. The black color was dominant in samples taken from surface waters. The identified MPs were in different colors, including red, blue, white, black, purple, yellow, and green collected from the sediments. Among 131 collected MPs in samples taken from sediments, 42, 18, 3, 58, 7, 2, and 1 ones were red, blue, white, black, purple, yellow, and green, respectively. The black color was dominant in samples taken from the sediments, too. The color-based categories of MPs were performed for fish species, too. Accordingly, in $L$. abu, 7, 3, 4, and 16 MPs were black, white, red, and blue, respectively. The blue color was dominant in this fish species. The color composition of the collected MPs in S. forsteri was as follows: 4, 2, 10, and 8 MPs as black, white, red, and blue, respectively. The red color was dominant in samples taken from this species (Fig. 5).

Also, in S. forsteri and C. arel, colors were identified, and the color composition of MPs was in these two species as follows: $S$. forsteri: 9, 2, 3, and 3 MPs as black, red, blue, and green, respectively. The black color was dominant in samples taken from this species; C. arel: 12, 4, 7 MPs as black, red, and blue, respectively. The black color was dominant in samples taken from this specie, too.

\subsection{Surficial textural characteristics and chemical composition of the MPs}

Figure 6 shows the results obtained from the analysis of the SEM images. Generally, MPs materials appeared with different surfaces of non-smooth, smooth, and edged shapes. The fibre MPs were observed as narrow and smooth shapes (Fig. 6B, H). Fragment MPs appeared with non-smooth structures (Fig. 6A, C, D, and F) and irregularly edged shapes (Fig. 6G). Also, film MPs showed an irregularly edged shape with a soft texture (Fig. 6E).

The analysis results of X-ray diffraction (EDS) spectroscopy revealed some elements such as carbon (C), oxygen (O), iron (Fe), aluminum (Al), silicon (Si), calcium (Ca), magnesium (Mg), and potassium (K) in the structures of MPs.

Carbon and oxygen are the main components of the structure of plastic material (do Sul and Costa, 2014), which constituted the most critical MPs composition analyzed in the present work. Also, trace silicon is applied in polymeric materials (Mehdinia et al., 2020). Other elements such as iron, aluminum, calcium, potassium, and magnesium can be absorbed by MPs from the surrounding area (Liu et al., 2019; Shruti et al., 2019), or they can be used as chemical additives in the production process of plastic materials (do Sul and Costa, 2014).

The cracks and abrasions observed on the surface of MPs indicate the period of MPs exposure to the environment, weathering by physical or chemical agents, or mechanical degradation occurred in larger pieces of plastics (Abbasi et al., 2017; Liu et al., 2019). These developed structures on the surfaces of MPs have already intensified their capacity to absorb various environmental pollutants, including heavy metals and organic pollutants (such as stable organic pollutants and polycyclic aromatic hydrocarbons) (Wardrop et al., 2016; Wen et al., 2018).

Reference hummel polymer sample library were used to identify MPs polymer in sample. Polymers that matched more than $70 \%$ with reference polymers were approved.

Overall, after assessing 357 identified MPs in the present study, we found that PE was the dominant polymer (43.15\%) in the collected MPs. Other identified polymers included PP (25\%), PS (18.75\%), PVAC (6.25\%), and PVPR (6.25\%) in the identified MPs (Fig. 7).

After assessing the identified MPs in the studied samples in this work, the major polymers were PE, PP, and PS in all the studied sampling regions.

\section{Discussion}

Fish can intake MPs for several reasons. They can mistake plastics for bait or ingest them during filter feeding (Sun et al., 2019). Also, Abbasi (2018) indicated that MPs are unlikely to accumulate in the digestive tract and the gut retention time of MPs consumed was the same as the ingested food.

Regarding the size of the MPs the most predominant size in any of the compartments was around 0.7-1mm, which is within the usual range founded in these environments. Only a few percentages is close to the range of mesoplastics (5 mm) according to the classification of Gregory and Andrady (2003). 
We found that the most typical shape of the MPs is the fiber. This is consistent with several previous works (Martin et al., 2017; Willis et al. 2019; Aliabad et al. 2019 and Kor and Mehdinia, 2020. Most of these works are also located in the south of Iran and they relate the presence and shape of MPs with the existence of fishing and commercial ports and the tourist industry.

Regarding the color the most dominant was black in sediments and seawater, which can be explained by the photoxidation due to the light exposition. In fish species, excepting $S$. forsteri, blue color was the dominant one. The colors of MPs can be applied to initially assess the origins and types of chemical compounds, and also the source of MPs. However, colors can change by weathering and the formation of biofilms; therefore, this results in a nearly controversial discussion about colors. The high frequency of colored fibers can be explained by the synthetic textiles such as clothing and carpets from beach dwellers in these areas or the fishing industry (ropes and fishing equipment).

Sampling regions that mostly were fishing and commercial ports, such as Bushehr, Bandar Abbas and Qeshm have the predominant polymers PP and PE in samples taken from surface water. As expected, PP and PE (with lower density) were the predominant polymers in surface water, contrary to the denser ones dominant in the sediments, due to the presence of fishing equipment, ropes, and boats.

Statistical analysis (one way-Anova) showed that in 0 . ruber, there was no significant relationship between the numbers of MPs in samples taken from water and sediment $(P>0.05)$ Also, the numbers of MPs did not show any significant relationship between the samples taken from water and sediment in L. abu species.

Statistical analysis showed that there were no significant relationships among the numbers of MPs, body length, body weight, and weight of the digestive system in S. forsteri, L. abu and $O$. ruber. But in C. arel, there were significant relationships among the numbers of MPs, body weight, body length, and weight of the digestive system $(\mathrm{P}<0.05)$.

In regions accommodated with the fishing industry, MPs can expand to include the usual wore and tore fishing nets and other marine equipment. Plastic cages, floating nets, and boats exposed to air and ultraviolet light can involve making plastic parts. The most well-known forms of MPs found as bulks in sediments and water sampled from fishing ports are constituted from the remains of vessels, fishing nets, boat hulls, and fragmented ropes, which is usually made of polyester and polyethylene (Thushari and Senevirathna 2020; Fu et al., 2020), this study showed that the dominate polymer in sampling regions in Persian gulf was polyethylene. Several factors involved in increased MPs including, tourism activities, recreational and commercial boating, and dwelling buildings by beaches (De Sales-Ribeiro et al., 2020; Rasta et al., 2020). Frey et al. (2014) suggested tourism and fishing industries as essential factors to raise the levels of MPs. In this study Bushehr, Bandar Abbas and Qeshm, also had these factors and were introduced as one of the most contaminated areas in this study.

\section{Conclusion}

In this study, MPs contamination levels were studied in samples taken from surface waters, sediments, and four studied fish species in 7 sampling stations located in the northern shores of the Persian Gulf. The stations were found to be different in terms of MPs contamination. Most of the MPs identified in all three sampling items were in the form of fibers. Some of the collected samples of MPs were from the remnants of fishing nets and ropes and fragments of vessels attached to the same nets. Tourism industry in some areas such as Bushehr, Qeshm and Bandar Abbas may be the most important cause for MPs pollution. In general, this study confirmed the pollution throughout the sediments and surface waters of these areas. Apparently, because of the danger posed by MPs waste to marine environments, there is a need for global decision-making by governments and environmental organizations to reduce the use of plastics and prevent this waste from entering marine environments.It is also suggested that MPs contamination must be investigated in the fish food chain of these areas.

\section{Declarations}

\section{Acknowledgements}

This study was financially supported by the Iran National Science Foundation, Iran (Grant No: 96016853).

\section{Ethical statement}

The authors pledged that no data from this study have been published elsewhere.

\section{References}

1. Abbasi S (2018) Microplastics in different tissues of fish and prawn from the Musa Estuary, Persian Gulf. J Chemosphere 205:8087. http://hdl.handle.net/10026.1/11614

2. Akdogan Z, Guven B (2019) Microplastics in the environment: a critical review of current understanding and identification of future research needs. Environ Pollut 113011. https://doi.org/10.1016/j.envpol.2019.113011.

3. Aliabad MK, Nassiri M, Kor K (2019) Microplastics in the surface seawaters of Chabahar Bay, Gulf of Oman (Makran Coasts). Mar Pollut Bull 143:125-133.doi: 10.1016/j.marpolbul.2019.04.037. 
4. Arias AH, Ronda AC, Oliva AL, Marcovecchio JE (2019) Evidence of microplastic ingestion by fish from the Bahía Blanca estuary in Argentina, South America. Bull Environ Contam Toxicol 102 (6), 750-756. https://doi.org/10.1007/s00128-019-02604-2.

5. Arthur C, Baker J, Bamford H (2009) Effects and fate of microplastic marine debris. In: Proceedings of the International Research Workshop on the Occurrence, Silver Spring, September 9-11, 2008. NOAA Technical Memorandum NOS-OR \& R30.NOAA (2009).

6. Auta HS, Emenike CU, Fauziah SH (2017) Distribution and importance of microplastics in the marine environment: a review of the sources, fate, effects, and potential solutions. Environ Int 102, 165-176. https://doi.org/10.1016/j.envint.2017. 02.013.

7. Bakir A, Rowland SJ, Thompson RC (2014) Transport of persistent organic pollutants by microplastics in estuarine condition. Estuar Coast Shelf Sci 140, 14-21. http:// dx.doi.org/10.1016/j.ecss.2014.01.004.

8. Bibak M, Sattari M, Tahmasebi S, Kafaei R, Sorial GA, Ramavandi B (2020) Trace and Major Elements Concentration in Fish and Associated Sediment-Seawater, Northern Shores of the Persian Gulf. Biol Trace Elem. Res https://doi.org/10.1007/s12011-020-02370-x.

9. Christaki U, Dolan JR, Pelegri S, Rassoulozadegan F (1998) Consumption of picoplankton-size particles by marine ciliates: Effects of physiological state of the ciliate and particle quality. Limnolgy and Oceanography doi.org/10.4319/lo.1998.43.3.0458.

10. Claessens M, De Meester S, Van Landuyt L, De Clerck K, Janssen CR (2011) Occurrence and distribution of microplastics in marine sediments along the Belgian coast. Mar Pollut Bull 62 (10), 2199-2204. https://doi.org/10.1016/j.marpolbul. 2011.06.030.

11. Cole M, Lindeque P, Halsband C, Galloway TS (2011) Microplastics as contaminants in the marine environment: a review. Mar Pollut Bull 62 (12).

12. Corcoran PL, (2015) Benthic plastic debris in marine and fresh water environments. Environ Sci Process Impacts 17 (8), $1363-1369$. https://doi.org/10.1039/ C5EM00188A.

13. De Sales-Ribeiro C, Brito-Casillas Y, Fernandez A, Caballero MJ (2020) An end to the controversy over the microscopic detection and effects of pristine microplastics in fish organs. Sci Rep 24;10(1):12434. doi: 10.1038/s41598-020-69062-3.

14. Du J, Xu S, Zhou Q, Li H, Fu L, Tang J, Wang Y, Peng X, Xu Y, Du X (2020) A review of microplastics in the aquatic environmental: distribution, transport, ecotoxicology, and toxicological mechanisms. Environ Sci Pollut Res Int 27(11):11494-11505. doi: 10.1007/s11356-020-08104-9.

15. Ferreira P, Fonte E, Soares ME, Carvalho F, Guilhermino L (2016) Effects of multi-stressors on juveniles of the marine fish Pomatoschistus microps: Gold nanoparticles, microplastics and temperature. Aquatic Toxicology.

16. Free CM, Jensen OP, Mason SA, Eriksen M, Williamson NJ, Boldgiv B (2014) High-levels of microplastic pollution in a large, remote, mountain lake. Mar Pollut Bull 85:156-163.

17. Fu Z, Chen G, Wang W, Wang J (2020) Microplastic pollution research methodologies, abundance, characteristics and risk assessments for aquatic biota in China. Environ Pollut. Nov; 266 (Pt 3):115098. doi: 10.1016/j.envpol.2020.115098.

18. Gouin T (2020) Toward an Improved Understanding of the Ingestion and Trophic Transfer of Microplastic Particles: Critical Review and Implications for Future Research. Environ Toxicol Chem 39(6):1119-1137. doi: 10.1002/etc.4718.

19. Gregory MR, Andrady AL (2003) Plastics in the marine environment. In: Andrady, Anthony.L. (Ed.), Plastics and the Environment. John Wiley and Sons, ISBN 0-471-09520-6.

20. Hermabessiere L, Dehaut A, Paul-Pont I, Lacroix C, Jezequel R, Soudant P, Duflos G(2017) Occurrence and effects of plastic additives on marine environments and organisms: a review. Chemosphere 182, 781-793. https://doi.org/10.1016/j. chemosphere.2017.05.096.

21. Hirai H, Takada H, Ogata Y, Yamashita R, Mizukawa K, Saha M, Kwan C, Moore C, Gray H, Laursen D, Zettler ER, Farrington JW, Reddy CM, Peacock EE, Ward MW (2011) Marine Pollution Bulletin, 29 Jun 2011, 62(8):1683-1692. doi: 10.1016/j.marpolbul.2011.06.004.

22. Holmes LA, Turner A, Thompson RC (2012) Adsorption of trace metals to plastic resin pellets in the marine environment. Environ Pollut $160,42-48$. doi: 10.1016/j.envpol.2011.08.052.

23. Hosseini R, Hossein Sayadia M, Aazami J, Savabieasfehanic M (2020) Accumulation and distribution of microplastics in the sediment and coastal water samples of Chabahar Bay in the Oman Sea, Iran. Mar Pollut Bull Volume 160, November 2020, 111682. https:// doi.org/ 10.1016/ j.marpolbul.2020.111682.

24. Kashiwada S (2006) Distribution of nanoparticles in the see-through medaka (Oryzias latipes), Environ Health Perspect https://doi.org/10.1289/ehp.9209

25. Kor K, Mehdinia A (2020) Neustonic microplastic pollution in the Persian Gulf. Mar Pollut Bull Volume 150, January 2020, 110665. doi.org /10.1016/ j.marpolbul. 2019. 110665.

26. Lithner D, Larsson A, Dave G (2011) Environmental and health hazard ranking and assessement of plastic polymers based on chemical composition. Sci Total Environ Volume 409, Issue 18, PP. 3309-3324. https://doi.org/10.1016/j.scitotenv.2011.04.038

27. Löder MGj, Gerdts G (2015) Methodology used for the detection and identification of microplastics-a critical appraisal. In: Bergmann, M., Gutow, L., Klages, M. (Eds.), Marine Anthropogenic Litter. Springer, Cham, pp. 201-227. https://doi.org/10. 1007/978-3-319-16510-3_8.

28. Martin J, Lusher A, Thompson RC (2017). The Deposition and Accumulation of Microplastics in Marine Sediments and Bottom Water from the Irish Continental Shelf Sci Rep 7, 10772 https://doi.org/10.1038/s41598-017-11079-2.

29. Martins J, Sobral P (2011) Plastic marine debris on the Portuguese coastline: a matter of size? Mar Pollut Bull 62 (12), $2649-2653$. https://doi.org/10.1016/j.marpolbul. 2011.09.028.

30. Neves D, Sobral P, Lia Ferreira J, Pereira T (2015) Ingestion of microplastics by commercial fish off the Portuguese coast. Mar Pollut Bull Volume 101, Issue 1, PP. 119-126. https://doi.org/10.1016/j.marpolbul.2015.11.008. 
31. Pedà C, Caccamo L, Fossi MC, Gai F, Andaloro F, Genovese L, Perdichizzi A, Romeo T, Maricchiolo G (2016) Intestinal alterations in European sea bass Dicentrarchus labrax (Linnaeus, 1758) exposed to microplastics: preliminary results. Environ Pollut 212, 251-256. http://dx.doi.org/10.1016/j.envpol.2016.01.083.

32. Qiu Q, Tan Z, Wang J, Peng J, Li M, Zhan Z (2016) Extraction, enumeration and identification methods for monitoring microplastics in the environment. Estuar Coast Shelf Sci 176, 102-109. https://doi.org/10.1016/j.ecss.2016.04.012.

33. Rasta M, Sattari M, Taleshi MS, Namin JI (2020) Identification and distribution of microplastics in the sediments and surface waters of Anzali Wetland in the Southwest Caspian Sea, Northern Iran. Mar Pollut Bull 160, p.111541. https: //doi.org /10.1016/j.marpolbul. 2020.111541.

34. Roch S, Friedrich C, Brinker A (2020) Uptake routes of microplastics in fishes: practical and theoretical approaches to test existing theories. Sci Rep 2020 Mar 3;10(1):3896. doi: 10.1038/s41598-020-60630-1.

35. Rochman CM, Browne MA, Halpern BS, Hentschel BT, Hoh E, Karapanagioti HK, Rios-Mendoza LM, Takada H, The S, Thompson RC (2013) a. Classify plastic waste as hazardous. Nature 494, 169-171. 14;494(7436):169-71. doi: 10.1038/494169a.

36. Rochman CM, Tahir A, Williams SL, Baxa DV, Lam R, Miller JT, The FC, Werorilangi S, The SJ (2015) Anthropogenic debris in seafood: Plastic debris and fibers from textiles in fish and bivalves sold for human consumption. Scientific Reports.

37. Savoca S, Capillo G, Mancuso M, Bottari T, Crupi R, Branca C.Romano V, Faggio C. D'Angelo GN (2019) SpanòMicroplastics occurrence in the tyrrhenian waters and in the gastrointestinal tract of two congener species of Seabreams Environ. Toxicol. Pharmacol., 67 (2019), pp. 35-41

38. Saeed T, Al-Jandal N, Al-Mutairi A, Taqi H (2020) Microplastics in Kuwait marine environment: Results of first survey. Mar Pollut Bull 152 (2020) 110880. https://doi.org/10.1016/j.marpolbul.2019.110880.

39. Su L, Deng H, Li B, Chen Q, Pettigrove V, Wu C, Shi H (2019) The occurrence of microplastic in specific organs in commercially caught fishes from coast and estuary area of East China J Hazard Mater, 365 (2019), pp. 716-724. doi: 10.1016/j.jhazmat.2018.11.024.

40. Teuten EL, Saquing JM, Knappe DRU, Barlaz MA, Jonsson S, Björn A, Rowland SJ, Thompson RC, Galloway TS, Yamashita R, Ochi D, Watanuki Y, Moore C, Viet PH, Tana TS, Prudente M, Boonyatumanond R, Zakaria MP, Akkhavong K, Ogata Y, Hirai H, Iwasa S, Mizukawa K, Hagino Y, Imamura A, Saha M, Takada H (2009)Transport and release of chemicals from plastics to the environment and to wildlife, Biol. Sci. 364 (1526), 2027-2045, 2009

41. Thompson RC, Olsen Y, Mitchell RP, Davis A, Rowland SJ, John AW, McGonigle D, Russell AE (2004) Lost at sea: where is all the plastic? Science 304 (5672), 838. https://doi.org/10.1126/science.1094559.

42. Thushari GGN, Senevirathna JDM (2020) Plastic pollution in the marine environment. Heliyon. 2020 Aug 27;6(8):e04709. doi: 10.1016/j.heliyon.2020.e04709.

43. Toumi H, Abidli S, Bejaoui M (2019) Microplastics in freshwater environment: the first evaluation in sediments from seven water streams surrounding the lagoon of Bizerte (Northern Tunisia). Environ. Sci. Pollut. Res. 26 (14), 14673-14682. https://doi.org/10.1007/s11356-019-04695-0.

44. Tourinho PS, Do Sul JAI, Fillmann G (2010) Is marine debris ingestion still a problem for the coastal marine biota of southern Brazil? Mar Pollut Bull.

45. Van Franeker JA, Blaize C, Danielsen J, Fairclough K, Gollan J, Guse N, Hansen P L, Heubeck M, Jensen JK, Le Guillou G, Olsen B (2011) Monitoring plastic ingestion by the northern fulmar Fulmarus glacialis in the North Sea. Environ Pollut 159(10):2609-15. doi: 10.1016/j.envpol.2011.06.008.

46. Von Moos N, Burkhardt-Holm P, Kohler A (2012) Uptake and effects of microplastics on cells and tissue of the blue mussel Mytilus edulis after an experimental exposure. Environ Sci Technol 16;46(20):11327-35. doi: 10.1021/es302332w.

47. Willis KA, Eriksen R, Wilcox C, Hardesty BD (2017) Microplastic Distribution at Different Sediment Depths in an Urban Estuary. Front Mar Sci 4:419. doi: 10.3389/fmars.2017.00419.

48. Wright SL, Rowe D, Thompson RC, Galloway TS (2013) Microplastic ingestion decreases energy reserves in marine worms. Curr Biol 23(23): R1031R1033. doi:10.1016/j.cub.2013.10.068.

49. X Sun QJ, Li, YQ, Shi YF, Zhao S, Zheng JH, Liang T, Liu ZY (2019) Tian Characteristics and retention of microplastics in the digestive tracts of fish from the Yellow Sea Environ. Pollut., 249 pp. 878-885

50. Zhu L, Wang H, Chen B, Sun X, Qu K, Xia B (2019) Microplastic ingestion in deep sea fish from the South China Sea. Sci Total Environ 677, $493-501$. https://doi.org/ 10.1016/j.scitotenv.2019.04.380.

\section{Figures}




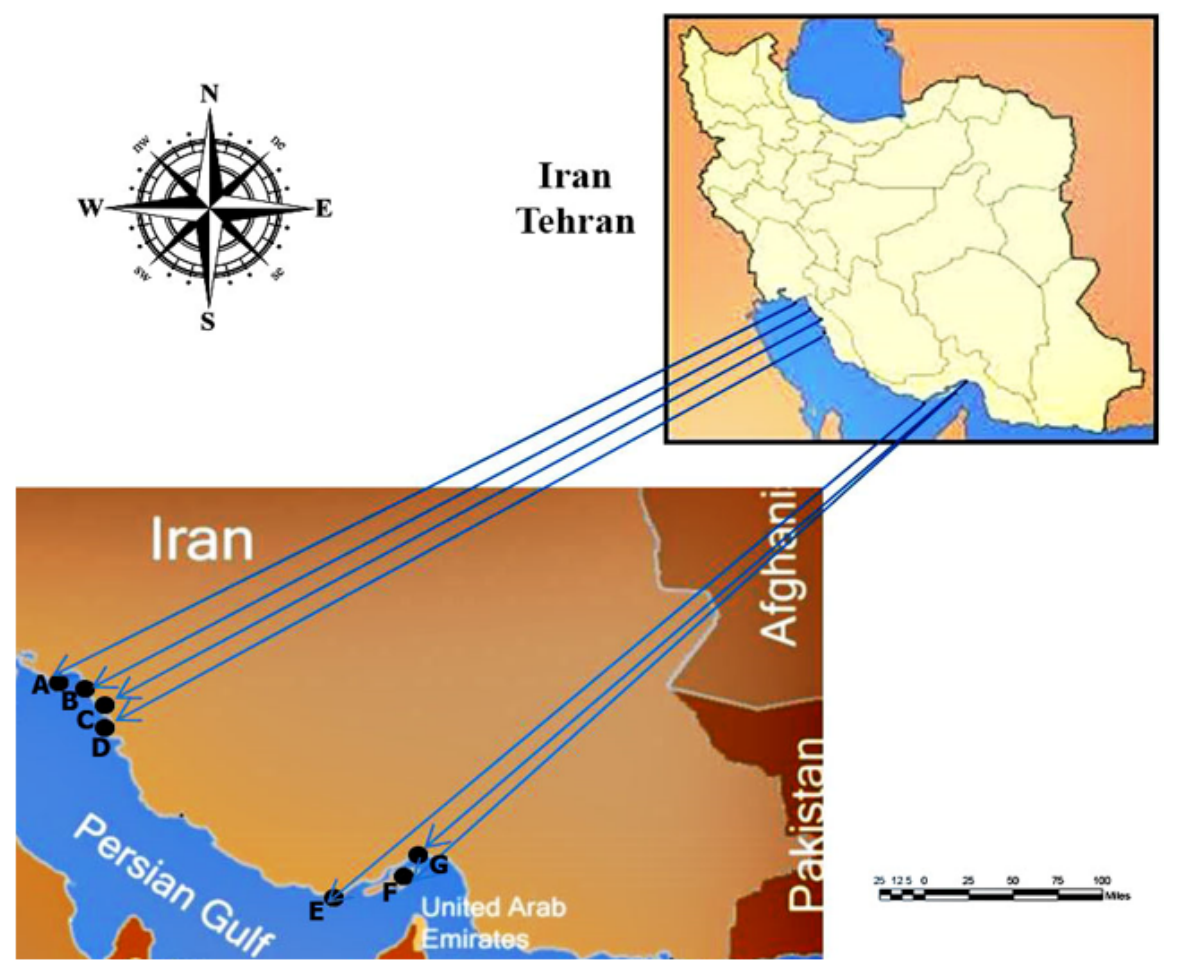

Figure 1

sampling region: A (Hendijan), B (Emam Hassan), C (Genaveh), D (Bushehr), E (Lengeh), F (Qeshm), G (Bandar Abbas)

O. ruber

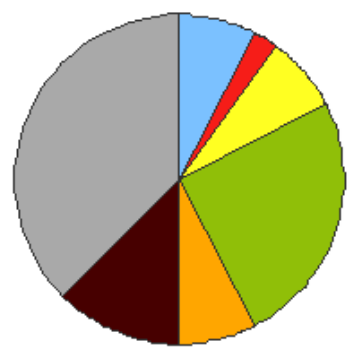

C. arel

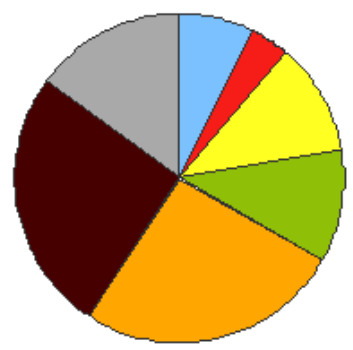

L. abu

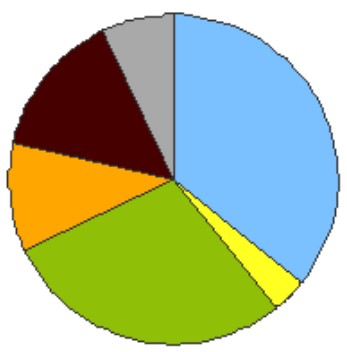

sediment

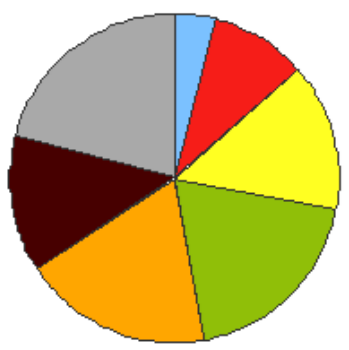

S. forsteri

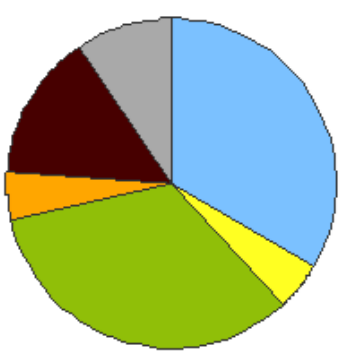

sea water

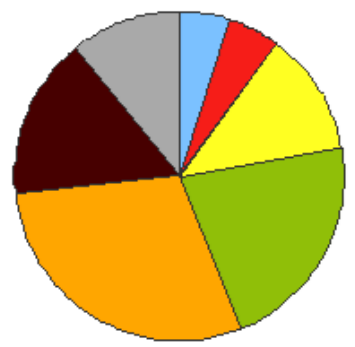

\begin{tabular}{|ll|} 
& Category \\
$\square$ & Hendijan \\
Genaveh \\
$\square$ EmamHassan \\
Bushehr \\
Bandar Abbas \\
Lengeh \\
Qeshm \\
\hline
\end{tabular}

Figure 2

The number of MPs per sampling items in different regions 

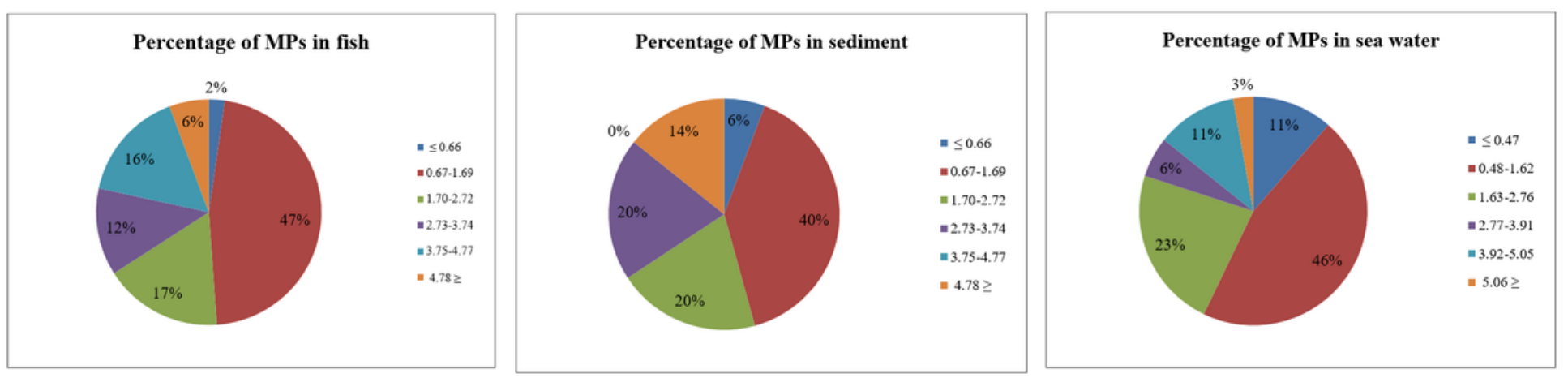

\section{Figure 3}

Percentage of size classification of MPs in fish, sediment and seawater

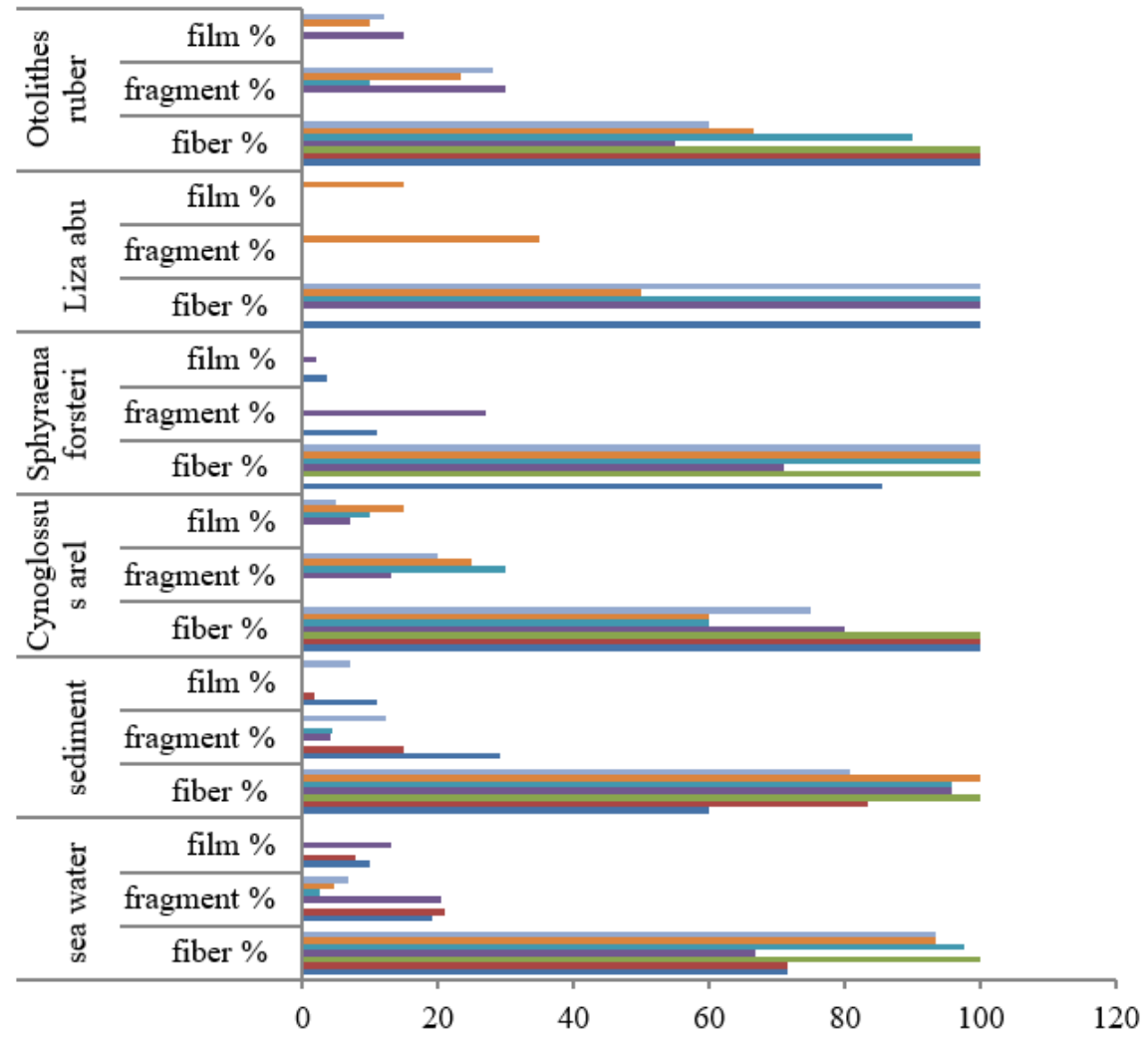

\section{Figure 4}

Different shapes of MPs in seawater, sediment and fish in the seven studied regions 


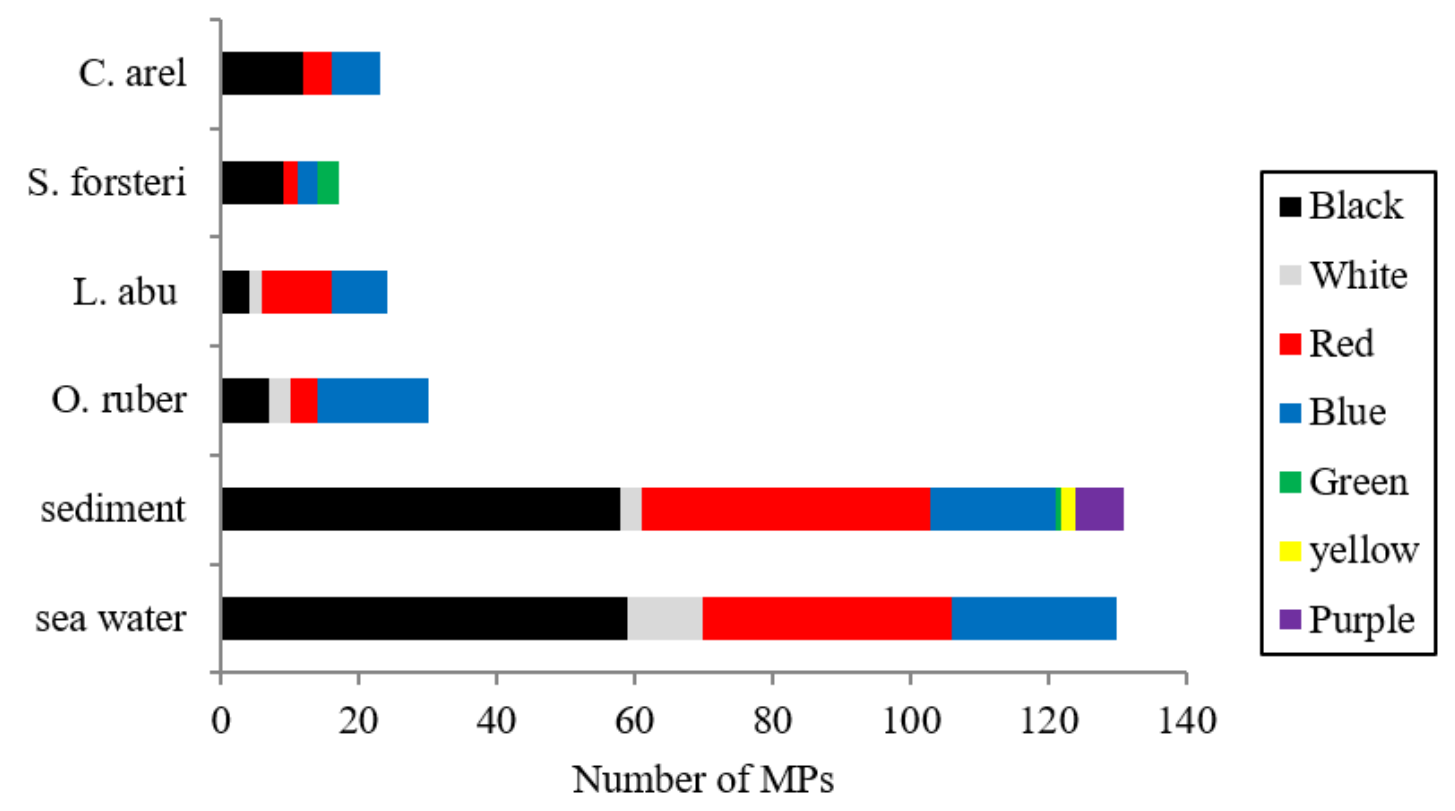

Figure 5

The color of MPs in sampling items

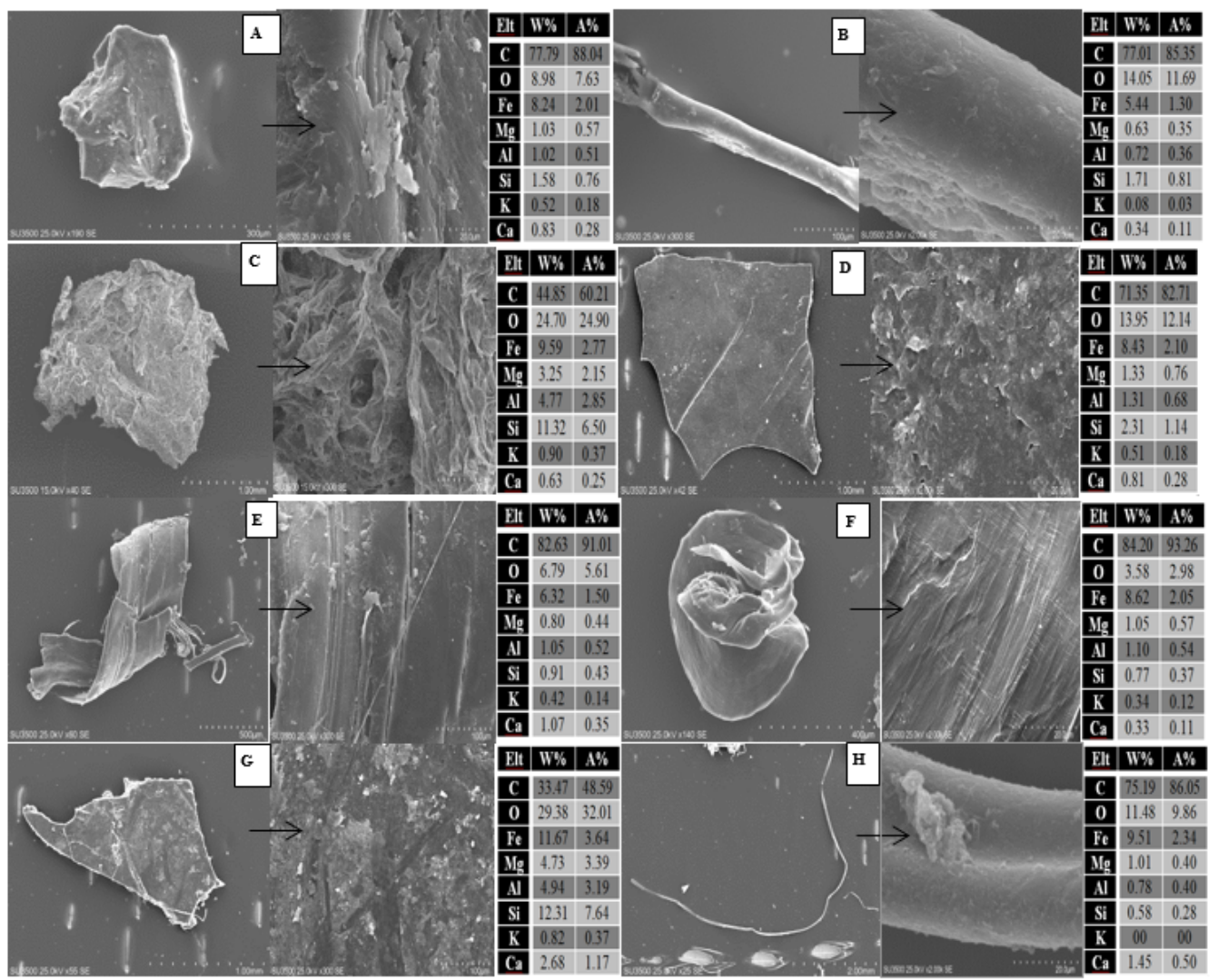

Figure 6

SEM / EDS analysis on sediment MPs (A: fragment, B: fiber), surface water (C and E: fragment, D: film) and fish digestive tract (F and G: fragment and H: fiber). 

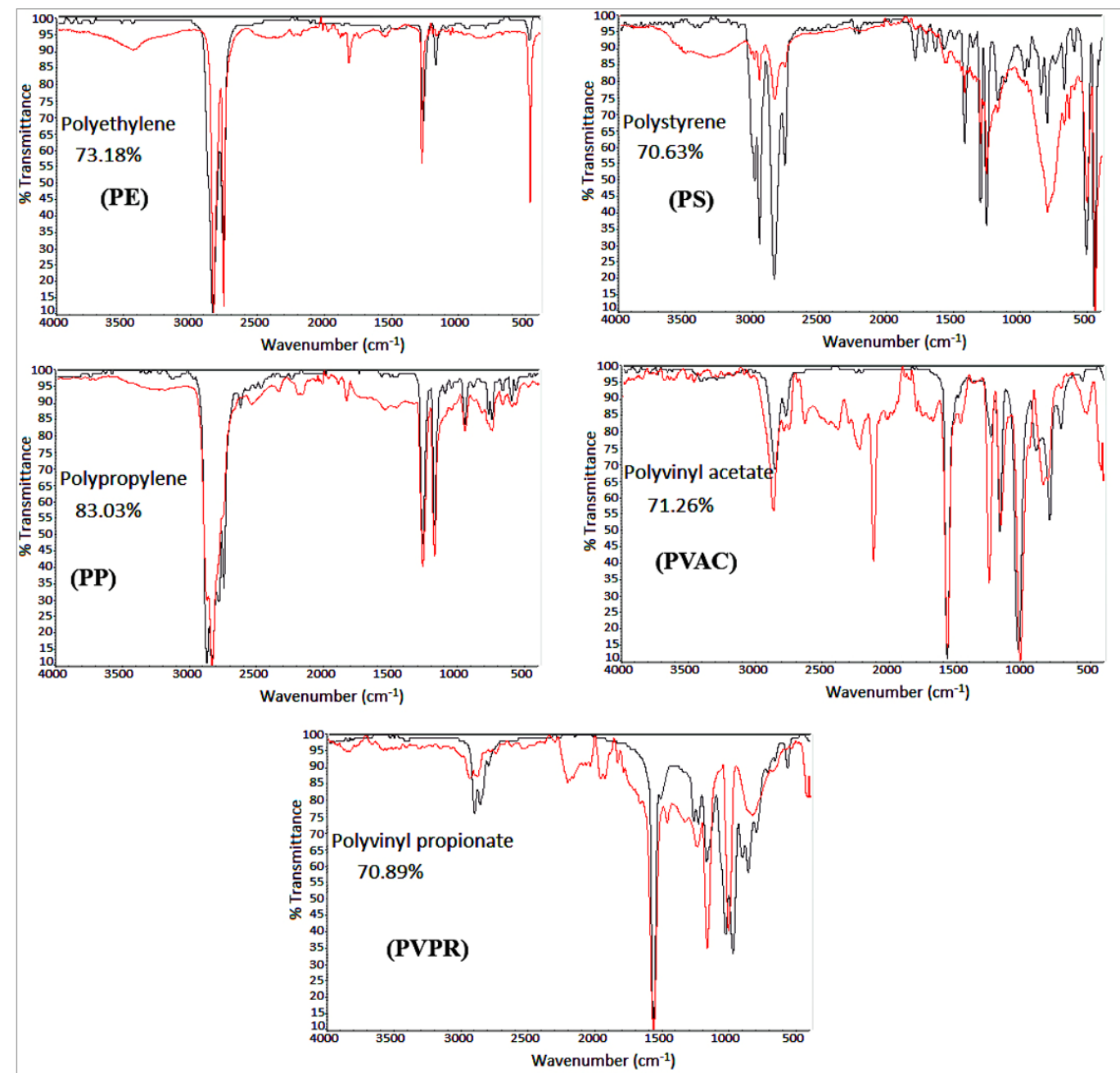

\section{Figure 7}

Identified polymers in sediment, surface water and gastrointestinal tract of fish; ATR-FTIR of representative samples identified in north of Persian Gulf (black line is polymer reference, red line is sample polymer) 